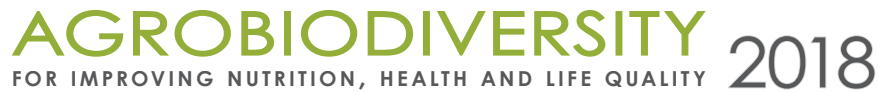

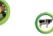

\section{BIOCHEMICAL COMPOSITION POLYMNIA SONCHIFOLIA POEPP. AT THE DOUBLE CUTTING}

\author{
Andrushchenko Olena*1, Vergun Olena ${ }^{1}$, \\ Fishchenko Valentyna ${ }^{1}$, Mishchenko Lidiya ${ }^{2}$ \\ ${ }^{1}$ M.M. Gryshko National Botanical Garden of NAS of Ukraine, Cultural Flora Department, Kyiv, Ukraine
${ }^{2}$ Taras Shevchenko National University of Kyiv, Educational and Scientific Centre "Institute of
Biology and Medicine“, Virology Department, Kyiv, Ukraine
}

Received: 17.09. 2018 Revised: 28. 10.2018 Published: 10. 12. 2018

Cultivation of Polymnia sonchifolia Poepp. in Ukraine does not guarantee a stable crop of root tubers, therefore, we are studied the possibility of using aboveground biomass of plants. Both tubers and extract of leaves reveal hypoglycemic effect (Kim et al., 2010). Plants of $P$. sonchifolia cv. Yudinka were used in this study. Leaves mass was cut twice on season to obtain maximal quantitative of plant raw material. The absolutely dry matter was determined by drying of plant raw material to constant mass; total content of sugars - by Bertrand method; concentration of ascorbic acid (AA) - by a 2.6-dichlorophenol-indophenol method; concentration of total carotene - using extraction with rubber solvent (petrol); the total lipid content was extracted with petroleum ether in Soxhlet extractor. The productivity of plant raw material at the double cutting was 22 t.ha ${ }^{-1}$, whereas at the cutting once on season was obtained 12 t.ha ${ }^{-1}$. Cutting promotes rejuvenation of plants and stimulates synthesis of biologically active compounds. In this case was observed increasing of yield of plants, content of dry matter and basic biochemical compounds of plants. Potential yield of content of dry mass of two cuttings were 3.08 t.ha ${ }^{-1}$, while one cutting 2.16 t.ha $^{-1}$. Total content of sugars was higher in the young organs of shoot. Content of AA was higher in young leaves in the August than in October - 302.68 and 201.37 mg\% respectively. The content of carotene decreased from 4.01 to $0.62 \mathrm{mg} \%$ during summer-autumn growing period. Quantity of lipids wasn't significant (1.25-3.60\%), but the most content was found in the leaves.

Keywords: Polymnia sonchifolia, dry matter, total content of sugars, ascorbic acid, carotene

\section{Introduction}

Modern methods of glycaemia phytotherapy provide the use of plants with sugar-reducing, cytoprotective and immunostimulating properties (Kikhtyak, 1998; Jia et al., 2003). Polymnia sonchifolia Poepp., that originates from South America and belongs to Asteraceae family, is characterized the above properties. Numerous scientific investigations proved the hypoglycemic action of $P$. sonchifolia (Khokhla et al., 2015, 2016). Traditionally, the root tubers were known as medicinal plant raw material but it's also proved the effectiveness of use of

*Corresponding author: Olena Andrushchenko, Timiryazevska str., 1, Kyiv, Ukraine, 01014, $\checkmark$ novaflora@ukr.net 
leaves extracts for the decreasing of sugar level in the blood (Aybar and Riera, 2001; Kim et al., 2010; Mishchenko et al., 2012). P. sonchifolia leafe tea is used as medicinal remedy by locals in Latin America (Manrique et al., 2005). Aboveground part of this plant included to content of hypoglycemic phytotea that was produced in Ukraine (Pat. No 86475, 2013). Moreover, as plant with high physiological activity $P$. sonchifolia has valuable content of biogenic elements, flavonoids, phytosterols, polysaccharides, polyunsaturated fatty acids etc. (Lachman et al., 2003; Dashchenko etal., 2016). It is known, that leaves of these plants content high quantitative of phenolic compounds that determines the antioxidant properties of $P$. sonchifolia and makes possible using of plant raw material in human ration as protective and preventive remedies at the chronic illness such as atherosclerosis (Valentova and Ulrichova, 2003). From $P$. sonchifolia it is possible to make products for special medical purposes: extracts and powders (Motuzka, 2017).

At the place of origin the high of plants is 1.5-2.5 m (Manrique et al., 2005). Although the most favorable is subtropical climate, plants able to grow in the temperate climate. Cultivation of $P$. sonchifolia in conditions of Ukraine possible with cutting at the greenhouse conditions (Mishchenko et al., 2018). Obtaining high yield of tubers in the drought conditions can be problematic but aboveground part of plant is a valuable raw also.

There is a need of study of productive plant potential and their biochemical composition in the perspective of industrial use.

\section{Material and methodology}

\section{Material}

Plant material of P. sonchifolia cv. Yudinka was used in this study.

\section{Experiment organization}

Study of plants were conducted on experimental collection of M.M. Gryshko National Botanical Garden of the NAS (NBG) of Ukraine (Right Bank Forest-Steppe). The soil is dark-grey, podzolized, eroded. Planting scheme was $50 \times 50 \mathrm{sm}$. First yield of biomass was conducted at $3^{\text {th }}$ August with cutting of apex of stem on the heigh of $20 \mathrm{sm}$ from the surface of soil; second yield $-1^{\text {st }}$ October. Analyses were performed at the biochemical laboratory of Cultural Flora department of NBG.

\section{Methodology of biochemical substances content}

The absolutely dry matter determined by drying of plant raw material for constant mass at the $105{ }^{\circ} \mathrm{C}$ according to Yermakov et al. (1972). Total content of sugars was investigated by Bertrand method in water extracts; concentration of ascorbic acid (AA) of the acid extracts was determined by a 2.6-dichlorophenol-indophenol method that based on the reduction properties of AA. Both analyses carried out according to Krishchenko (1983). Concentration of total carotene determined according to Pleshkov (1985) using extraction with rubber solvent (petrol). The procedure of determination of total lipid level was performed using Soxhlet 
extractor. Plant raw material was extracted with petroleum ether (boiling temperature is $40-60^{\circ} \mathrm{C}$ ) according to Yermakov et al. (1972).

\section{Results and discussion}

P. sonchifolia can grow without the formation of root tubers under conditions of industrial cultivation in the forest-steppe zone of Ukraine. We did an experiment in which the plants first used apical leaves, and then all biomass: leaves, stems and rhizomes. Since in August it is possible to use only apical leaves, the analysis of stems and rhizomes was not performed at this time.

The biochemical composition of P. sonchifolia in literary notes is mainly given at the time of harvesting of tubers. As a rule, it is investigated tubers. It is given that in yacon roots contains 69-93\% water (King, 1987; Grau and Rea, 1997; Valentova and Ulrichova, 2003). According to our data, most of the water found in young leaves and stems (86 and 88\% respectively) (Table 1). Most authors report the sugar content in tubers, which range from 12.5 (Valentova and Ulrichova, 2003) to $29 \%$ of total dry weigth (Asami et al., 1989). According to our data, the content of sugars increases in sequence: leaves < stems < rhizomes (Table 2). This is also confirm by studies Fukai et al. (1993). The content of ascorbic acid and carotene was rarely given in the literary notes by researchers. Grau and Rea (1997) report data on ascorbic acid and carotene content in the roots (13 and $0.08 \mathrm{mg}^{-\mathrm{g}^{-1}}$ respectively). Valentova and Ulrichova (2003) found carotene in tubers of $0.02 \mathrm{mg} .100 \mathrm{~g}^{-1}$. The content of lipids in tubers significantly different depending on the variety (191-311 mg.100 g-1) according to Manrique et al. (2005). Valentova and Ulrichova (2003) reported that most lipids are in leaves (4.20\%) less than in the stems (1.98\%) and tubers (0.10-0.30\%).

In our experiments, cutting of $P$. sonchifolia leaves mass was used twice on season to obtain maximal quantitative of plant raw material. After deleting of shoot leading of experimental plants on the main stems were grown lateral shoots, that formed new leaves mass. Second time the yield was collected $1^{\text {st }}$ October. The comparative analyze conducted with plants which didn't cut at all (control). It was found that productivity of plant raw material at the double cutting was significantly high and was 22 t.ha $^{-1}$, whereas at the cutting once on year was obtained 12 t.ha $^{-1}$.

Qualitative content of plant raw material was determined by biochemical composition. It was noticed that content of dry mass accumulated more in all organs of plants that were cut once. This fact possible to explain, that the experimental plant above-ground organs were younger, than control. In the leaves of first and second cutting content of dry matter was approximately $14.00 \%$, in the control plants $-18.03 \%$ (Table 1). Evidence, double cutting not stimulates the accumulation of dry mass in under-ground part of investigated plants because in the end of vegetation season in rhizomes it was 3\% less. Potential yield of content of dry mass of two cutting were 3.08 t.ha $^{-1}$, whereas, after one cutting 2.16 t.ha ${ }^{-1}$ only. 
Table 1 The content of dry matter in plant raw material of Polymnia sonchifolia Poepp. (\%)

\begin{tabular}{lcccccc}
\hline \multirow{2}{*}{ Part of plant } & \multicolumn{2}{c}{ First cutting* } & \multicolumn{2}{c}{ Second cutting** } & \multicolumn{2}{c}{ Non-cutting plants** } \\
\cline { 2 - 7 } & $M \pm m$ & $V(\%)$ & $M \pm m$ & $V(\%)$ & $M \pm m$ & $V(\%)$ \\
\hline Leaves & $13.88 \pm 0.43$ & 3.08 & $14.40 \pm 0.30$ & 2.10 & $18.03 \pm 0.73$ & 4.07 \\
Stems & & & $11.68 \pm 0.67$ & 5.76 & $14.48 \pm 0.30$ & 2.07 \\
Rhizomes & & & $15.89 \pm 1.17$ & 7.37 & $19.05 \pm 0.94$ & 4.94 \\
\hline
\end{tabular}

Notes: $M$ - arithmetic mean; $m$ - standard error of the mean; $V(\%)$ - variation coefficient; ${ }^{*}$ Cut date $-3^{\text {th }}$ August; ${ }^{* *}$ Cut date $-1^{\text {th }}$ October

Total content of sugars was higher in young organs of shoot, that formed during two months. In the leave of experimental plants after second cutting was found $2 \%$ more sugars than in control plants (Table 2). In the stems and rhizomes level of total content of sugars increased. This trend saves in both - plants that were cut twice and plants without cutting. Root system of experimental and control plants, despite on organs of above-ground mass, had the same level of total content of sugars.

Table 2 The total content of sugar of plant raw material of Polymnia sonchifolia Poepp. (\%)

\begin{tabular}{lcccccc}
\hline \multirow{2}{*}{ Part of plant } & \multicolumn{2}{c}{ First cutting* } & \multicolumn{2}{c}{ Second cutting** } & \multicolumn{2}{c}{ Non-cutting plants** } \\
\cline { 2 - 7 } & $M \pm m$ & $V(\%)$ & $M \pm m$ & $V(\%)$ & $M \pm m$ & $V(\%)$ \\
\hline Leaves & $9.34 \pm 0.42$ & 6.37 & $12.43 \pm 0.51$ & 5.84 & $10.31 \pm 0.73$ & 10.13 \\
Stems & & & $29.33 \pm 0.29$ & 1.41 & $24.83 \pm 2.12$ & 12.08 \\
Rhizomes & & & $48.51 \pm 1.24$ & 3.62 & $48.73 \pm 0.34$ & 0.97 \\
\hline
\end{tabular}

Notes: $M$ - arithmetic mean; $m$ - standard error of the mean; $V(\%)$ - variation coefficient; ${ }^{*}$ Cut date $-3^{\text {th }}$ August; ${ }^{* *}$ Cut date $-1^{\text {th }}$ October

Content of ascorbic acid, the same as total content of sugars, had higher signs in the tissues of younger organs. The most difference found in plant raw material that collected $3^{\text {th }}$ August and in control plants during autumn period -302.68 and $201.37 \mathrm{mg} \%$ respectively (Table 3 ). Evidence, that collecting twice can give plant raw material with higher quality. Comparing under-ground and above-ground organs of plants showed that leaves prevailed by ascorbic acid content.

Table 3 Content of ascorbic acid in plant raw material of Polymnia sonchifolia Poepp. (mg\%)

\begin{tabular}{lcccccc}
\hline \multirow{2}{*}{ Part of plant } & \multicolumn{2}{c}{ First cutting* } & \multicolumn{2}{c}{ Second cutting** } & \multicolumn{2}{c}{ Non-cutting plants** } \\
\cline { 2 - 7 } & $M \pm m$ & $V(\%)$ & $M \pm m$ & $V(\%)$ & $M \pm m$ & $V(\%)$ \\
\hline Leaves & $302.68 \pm 3.06$ & 1.43 & $263.52 \pm 2.70$ & 1.45 & $201.37 \pm 2.16$ & 1.52 \\
Stems & & & $51.00 \pm 2.54$ & 7.05 & $44.94 \pm 2.05$ & 6.45 \\
Rhizomes & & & $46.14 \pm 1.87$ & 3.73 & $32.72 \pm 2.57$ & 11.10 \\
\hline
\end{tabular}

Notes: $M$ - arithmetic mean; $m$ - standard error of the mean; $V(\%)-$ variation coefficient; ${ }^{*}$ Cut date $-3^{\text {th }}$ August; ${ }^{* *}$ Cut date $-1^{\text {th }}$ October 
It is found less content of carotene accumulated in the tissues of plants of $P$. sonchifolia. It should be noticed that in autumn period content of that in the leaves significantly decreased (from 4.01 to $0.62 \mathrm{mg} \%$ ) if compare with value of $3^{\text {th }}$ August (Table 4 ). In young leaves, that formed during August-September content of carotenoids also was less $(0.24 \mathrm{mg} \%)$. Evaluation of plant raw material by this parameter showed that fraction of summer collecting is especially qualitative.

Table 4 Content of carotene in plant raw material of Polymnia sonchifolia Poepp. (mg\%)

\begin{tabular}{lcccccc}
\hline \multirow{2}{*}{ Part of plant } & \multicolumn{2}{c}{ First cutting* } & \multicolumn{2}{c}{ Second cutting** } & \multicolumn{2}{c}{ Non-cutting plants** } \\
\cline { 2 - 7 } & $M \pm m$ & $V(\%)$ & $M \pm m$ & $V(\%)$ & $M \pm m$ & $V(\%)$ \\
\hline Leaves & $4.01 \pm 0.01$ & 0.45 & $0.24 \pm 0.02$ & 10.74 & $0.62 \pm 0.03$ & 7.08 \\
Stems & & & $0.26 \pm 0.02$ & 7.95 & $0.25 \pm 0.02$ & 10.92 \\
Rhizomes & & & $0.14 \pm 0.01$ & 12.44 & $0.29 \pm 0.02$ & 7.29 \\
\hline
\end{tabular}

Notes: $\mathrm{M}$ - arithmetic mean; $\mathrm{m}$ - standard error of the mean; V,\% - variation coefficient; * Cut date $-3^{\text {th }}$ August; ${ }^{* *}$ Cut date $-1^{\text {th }}$ October

Content of compounds of lipophilic fraction in the leaves of $P$. sonchifolia also was higher in plants that were cut twice in season. Quantity of lipids wasn't significant (1.25-3.60\%), but the most content was found in the leaves (Table 5).

Table 5 Content of lipids in plant raw material of Polymnia sonchifolia Poepp. (\%)

\begin{tabular}{lcccccc}
\hline \multirow{2}{*}{ Part of plant } & \multicolumn{2}{c}{ First cutting* } & \multicolumn{2}{c}{ Second cutting** } & \multicolumn{2}{c}{ Non-cutting plants** } \\
\cline { 2 - 6 } & $M \pm m$ & $V(\%)$ & $M \pm m$ & $V(\%)$ & $M \pm m$ & $V(\%)$ \\
\hline Leaves & $3.60 \pm 0.14$ & 3.75 & $2.63 \pm 0.12$ & 4.69 & $1.99 \pm 0.02$ & 0.86 \\
Stems & & & $1.68 \pm 0.03$ & 1.85 & $1.25 \pm 0.02$ & 1.37 \\
Rhizomes & & & $1.63 \pm 0.03$ & 2.09 & $1.07 \pm 0.08$ & 7.63 \\
\hline
\end{tabular}

Notes: $\mathrm{M}$ - arithmetic mean; $\mathrm{m}$ - standard error of the mean; V,\% - variation coefficient; * Cut date $-3^{\text {th }}$ August; ${ }^{* *}$ Cut date $-1^{\text {th }}$ October

\section{Conclusions}

Cultivation of $P$. sonchifolia in conditions of Forest-Steppe of Ukraine for use as plant raw material for remedy and preventive products can be recommended to mowing it twice on season: in the beginning of August and in October. Cutting promotes rejuvenation of plants and stimulates synthesis of biologically active compounds. In this case was observed increasing of yield, content of dry matter and basic biochemical compounds of plants.

\section{References}

ASAMI, T., et al. 1989. Chemical composition of yacon, a new crop from the Andean Highlands. In Jpn. J. Soil Sci. Plant Nutr., vol. 60(2), p. 122-126. https://doi.org/10.20710/dojo.60.2_122 
AYBAR, M., RIERA, A.N.S. 2001. Hypoglycemic effect of the water extract of Smallanthus sonchifolius (yacon) leaves in normal and diabetic rats. In J. Ethnopharmacol, vol. 74(2), p. 125-132. https:// doi.org/10.1016/S0378-8741(00)00351-2

DASHCHENKO, A.V., et al. 2016. Novyi perspektyvnыi introdutsent (Polymnia sonchifolia Poepp.) v Ukraini [New promising alien species of yacon (Smallanthus sonchifolia (Poepp. et Endl.) H. Robinson) for medicinal plant cultivation in Ukraine]. In Agroecological Journal, vol. 2, p. 39-46. [In Ukrainian]. Available at: https://docplayer.net/71438878-Agroekologichniy-zhurnal.html

GRAU, A., REA, J. 1997. Yacon. Smallanthus sonchifolius (Poep. \& Endl.) H. Robinson. In Andean roots and tubers: Ahipa, arracacha, maca and yacon. Rome : IPGRI, p. 199-242. Available at: https:// www.bioversityinternational.org/fileadmin/_migrated/uploads/tx_news/Andean_roots_and_ tubers_472.pdf

JIA, W., GAO, W.Y., XIAO, P.G. 2003. Antidiabetic drugs of plant origin usedin China: compositions, pharmacology, and hypoglycemic mechanisms. In ZhongguoZhong Yao ZaZhi, vol. 28(2), p. 108-113.

FUKAI, K. et al. 1993. Distribution of carbohydrates and related enzyme-activities in yacon (Polymnia sonchifolia). In Soil Sci Plant Nutr., vol. 39(3), p. 567-71. http://dx.doi.org/10.1080/00380768.19 93.10419797

KHOKHLA, M. et al. 2015. Yacon (Smallanthus sonchifolius (Poepp. \& Endl.) H. Robinson) improved erythrocyte resistance to oxidative stress in streptozotocin-induced diabetic rats advances in diabetes and metabolism. In Advances in Diabetes and Metabolism, vol. 3(3), p. 17-25. http://www. hrpub.org/download/20151231/ADM1-17105341.pdf

KHOKHLA, M., et al. 2016. Yacon's (Smallanthus sonchifolius Poepp. and Endl.) effects on postprandial glucose under experimental diabetes mellitus. In Academia Journal of Pharmacy and Pharmacology, vol. 4(2), p. 29-36. http://dx.doi.org/10.15413/ajpp.2015.0436

KIKHTYAK, O.P. 1998. Patofiziolohichni aspekty pokaznykiv vuhlevodnoho obminu pry insulinnezalezhnomu tsukrovomu diabeti $\mathrm{v}$ umovakh fitoterapii [Pathophysiological aspects of carbohydrate metabolism in insulin-independent diabetes mellitus under phytotherapy]. In Experimental and Clinical Physiology and Biochemistry, vol. 1(1), p. 52-55. [In Ukrainian].

KIM, I.S., et al. 2010. Effect of fermented yacon (Smallanthus sonchifolius) leaves tea on blood glucose levels and glucose metabolism in high-fat diet and streptozotocin-induced type 2 diabetic mice. In Korean J Nutr., v. 43(4), p. 333-341. https://doi.org/10.4163/kjn.2010.43.4.333

KING, S.R., VIETMEYER, N.D. 1987. An evaluation of Andean root and tuber crops: genetic resources for mountain environments. In International workshop on mountain agriculture and crop genetic resources. New Delhi, Bombay, Calcutta : Oxfords IBH Pablishing co. PVT. LTD, p. 255-272. Available at: http://citeseerx.ist.psu.edu/viewdoc/download?doi=10.1.1.1030.12\&rep=rep1\&type=pdf

KRISHCHENKO, V.P. 1983. Metodyi otsenki kachestva rastitelnoy produktsii [Methods for evaluating the quality of plant production]. Moskva : Kolos, 192 p. [In Russian].

LACHMAN, J., FERNANDEZ, E.C., ORSAK, M. 2003. Yacon [Smallanthus sonchifolia (Poepp. \& Endl.). H. Robinson] chemical composition and use - a review. In Plant, Soil and Environment, vol. 49(6), p. 283-290. Available at: https://www.agriculturejournals.cz/publicFiles/52863.pdf

MANRIQUE, I., PARRAGA, A., HERMANN, M. 2005. Yacon syrup: Principles and processing. Conservacion y uso de la biodiversidad de raices y tuberculos andinos: Una decada de investigacion para el desarrollo (1993-2003). - No 8 B. Lima, Peru: International Potato Center, Universidad Nacional Daniel Alcides Carrion, Erbacher Foundation, Swiss Agency for Development and Cooperation. 31 p. Available at: http://cipotato.org/wp-content/uploads/2014/09/1919-Yacon_ Syrup.pdf

MISHCHENKO, L.T., et al. 2018. Sposib zhyvtsiuvannia yakonu (Polymnia sonchifolia Poepp.) [Method of cutting yakon (Polymnia sonchifolia Poepp.)]. In Proceedings of Sixth International Scientific and Practical Conference : Medicinal Herbs: from Past Experience to New Technologies. Lubny : Municipal 
publishing house «Lubny», p. 72-75. [In Ukrainian]. Available at: https://www.pdaa.edu.ua/sites/ default/files/node/2908/viconfpoltava2017ver2.pdf

MISHCHENKO, L.T., et al. 2012. Yakon: tekhnolohiia vyroshchuvannia, zbyrannia ta zberihannia posadkovoho materialu (Polimnia sonchifolia Poepp.) [Yakon: the technology of growing, harvesting and storage of planting material (Polimnia sonchifolia Poepp.)]. [Research guidelines]. Kyiv: Publishing and printing center «Kyyivs'kyy universytet». 27 p. [In Ukrainian].

MISHCHENKO, L.T., et al. 2013. Фіточай гіпоглікемічний з яконом. Patent № 86475 Ukraine, A23F 3/34. 4 p. [In Ukrainian] Available at: http://base.uipv.org/searchINV/search.php?action = viewdetails\&IdClaim $=195442$

MOTUZKA, I. 2017. Components of quality of products for special medical purposes. In Agrobiodiversity for improving nutrition, health and life quality, vol. 1, p. 334-337. http://dx.doi.org/10.15414/ agrobiodiversity.2017.2585-8246.334-337

PLESHKOV, B.P. 1985. Praktikum po biohimii rasteniy [Plant biochemistry workshop]. Moskva : Kolos. 256 p. [In Russian].

VALENTOVA, K., ULRICHOVA, J. 2003. Smallanthus sonchifolius and Lepidium meyenii - prospective Andean crops for the prevention of chronic diseases. In Biomed. Papers, vol. 147(2), p. 119-130. http://dx.doi.org/10.5507/bp.2003.017

YERMAKOV, A.I. et al. 1972. Metodyi biohimicheskogo issledovaniya rasteniy [The methods of biochemical investigations of plants]. Leningrad : Kolos. 456 p. [In Russian]. 